\title{
Methyl-CpG-Binding Domain Protein 3
}

National Cancer Institute

\section{Source}

National Cancer Institute. Methyl-CpG-Binding Domain Protein 3. NCI Thesaurus. Code C94736.

Methyl-CpG-binding domain protein 3 (291 aa, 33 kDa) is encoded by the human MBD3 gene. This protein is involved in transcription that is regulated by modifications for both DNA and histones. 